\title{
Morse Code Receiver on Invisible Light Using Background Subtraction Method
}

\author{
Yuda Irawan ${ }^{1}$, Refni Wahyuni ${ }^{2}$, Herianto ${ }^{3}$ \\ 1, 2,3 Department of Information System, STMIK Hang Tuah Pekanbaru, Pekanbaru, Indonesia \\ Email: ${ }^{1}$ yudairawan89@gmail.com, ${ }^{2}$ refniabid@gmail.com, ${ }^{3}$ herianto.sy@ gmail.com
}

\begin{abstract}
Morse code is a system of representation of letters, numbers, punctuation marks and signals using a code of dots and lines that are arranged to represent certain characters in the alphabet or certain signals (signs) that are agreed upon for use throughout the world. This code was coined by Samuel F.B. Morse and Alfred Vail in 1835. This research aims at how to apply the Background Subtraction method in the design of the morse sign language receiver in the invisible light. Build an Android-based application for recognition of Morse sign language by keeping messages sent using Morse sign language secret through infrared light from the sight of those who can read the message. From the results of the tests that have been carried out, it is concluded that the level of accuracy of testing using the False Match Rate (FMR) obtained a success percentage of $65 \%$ from the 26 -character data tested. From the 26-character data tested, it was obtained data with the number of characters that were successfully counted correctly, namely 17 characters, while the character data that failed to be counted was 9 characters with a detection result of 26 characters.
\end{abstract}

Keywords- Morse gesture, Microcontroller, Receiver, Invisible Light, Background Subtraction

\section{INTRODUCTION}

Morse code is a system of representation of letters, numbers, punctuation marks and signals using a code of dots and lines that are arranged to represent certain characters in the alphabet or certain signals (signs) that are agreed upon for use throughout the world was studied by nilas [1] and ching [3]. This code was coined by Samuel F.B. Morse and Alfred Vail in 1835 was studied by ming [2]. In the early days of its development in the 19th century until the mid-20th century, Morse code sent via telegraph was the communication medium with the widest and fastest reach, and became the main means of sending news in post offices was studied by wahyuni [4]. all over the world until the time the telephone became popular in society was studied by nguyen [5].

In Morse code the most commonly agreed and used signal is the "SOS" signal (...---...), which is a code used as a sign of danger that has been agreed upon by various international maritime treaties, and in several countries and regions use of this signal outside of an emergency situation may result in the threat of punishment was studied by irawan [6]. Morse code as an emergency signal from a ship in danger can be sent in the form of radio signals, sign lights, whistles or flags was studied by niu [7].
In addition, Morse code is also used and studied in the world of scouting was studied by murugan [8]. In the world of scouting, Morse code is conveyed using a scout flashlight or whistle was studied by subagjo [9]. The way to convey this Morse code is by turning on a flashlight with a short duration to represent a point and turning on a flashlight with a long duration to represent a line. However, not everyone can read this Morse code was studied by muhardi [10].

Background subtraction is a technique in the field of image processing and computer vision in which the foreground of the image is extracted for further processing (object recognition) was studied by lee [11]. Background Subtraction uses two models with high and low brightness levels was studied by cunnif [12]. Two models that have a high color value are called the maximum model and the low one is called the minimum model was studied by shanhu [13] and shanhu [14]. The maximum and minimum models are used to eliminate the background was studied by jiang [15], the current door security system only uses conventional locks and is considered less effective for security because only by using a wire people can break into the door security system and other problems sometimes due to locks was studied by song [16]. Conventional ones are often lost and even easily lost was studied by regain [17]. In today's technological advances, new innovations are created to create a sophisticated security tool or system was studied by zeng [18] and irawan [19]. The design of this system uses a password lock that is connected to a $4 \times 4$ keypad and Arduino UNO as a microcontroller with a door guard like this was studied by youwei [20], of course there will be no more cases of losing keys and is also expected to maximize security protection and minimize crime was studied by hao [21].

\section{METHODS}

This stage is the stage in finding initial information about studies that have been conducted by previous researchers regarding the design of an Android-based Morse sign language recognition application, as well as the Background Subtraction method on computer vision was studied by wahyuni [22]. The following are the stages of making the method:

\section{a. Data collection}

Literature study is carried out by studying information and data obtained from books was studied by chen [23], scientific journals and other related research as a guide in 
the research process of introducing Morse sign language using the Android-based Background Subtraction method was studied by fonda [24].

\section{b. Frame Extraction}

In the early stages, video files are captured and broken down into digital images based on video frames was studied by nalajala [25]. The extraction process is carried out on video where each frame at a certain time unit is converted into a digital image was studied by suparman [26]. The resulting digital image is in JPEG (Joint Photographic Experts Group) format. Furthermore, for each pixel in the digital image it is converted to double type which has a value range of 0 to 1 . A pixel value of 0 is for a weak color component and a value of 1 means a strong color component was studied by lenardo [27].

\section{c. Background Modeling}

Based on the image generated from the video recording, a background model is determined. Then the background image modeling process is carried out manually by selecting a digital image where there are no objects in it was studied by chen [28].

\section{d. Testing the System}

After the coding process is complete, it is continued with the system testing process after the software and tools are ready for use by the user, then the software and tools that have been made must perform testing before use was studied by silva [29]. This aims to minimize software and tool errors. This test will be carried out using the black box method was studied by irawan [30].

\section{e. System Evaluation}

In this system evaluation stage the user evaluates the system and tools that have been made as desired. if not, then the author will repeat steps to stages 4 and 5. But if so, then stage 7 will be carried out was studied by faudzi [31].

Data collection technique is consisting of preprocessing, background subtraction, image segmentations and object classification.

\section{a. Preprocessing}

The background image and the image obtained are normalized by the R, G and B components. Normalization is done to increase the accuracy of the image reduction process. To get a better image, before normalizing the Red $(\mathrm{R})$, Greeb (G) and Blue (B) color components was studied by fatmawati [32].

\section{b. Background Subtraction}

After the image has been normalized, then the image reduction process (background subtraction) is carried out by reducing every pixel in the object image with the background image. The image reduction process is done absolutely where the difference of every pixel of the two images will be obtained and always has a positive value. Because this technique will see the difference for each pixel in the image, so both images must have the same data type and size was studied by Wijaya [33].

\section{c. Image Segmentation}

In order for the image to be well segmented, several strengthening (dilatatio) and filling processes are carried out.

\section{d. Object Classification}

After the object is segmented properly, a selection is carried out by performing a classification so that the infrared light object and the non-infrared light object are obtained.

\section{IMPLEMENTATION}

The system implementation will be described in accordance with the analysis and design described in the previous chapter. After the analysis and design stages have been completed, then the next stage is the implementation of the interface design which aims to explain the implementation of the interface that has been designed so that it is in accordance with the expected. The results of the implementation of the application interface. The home page is the initial display of the system which will be displayed to the user Figure (1).

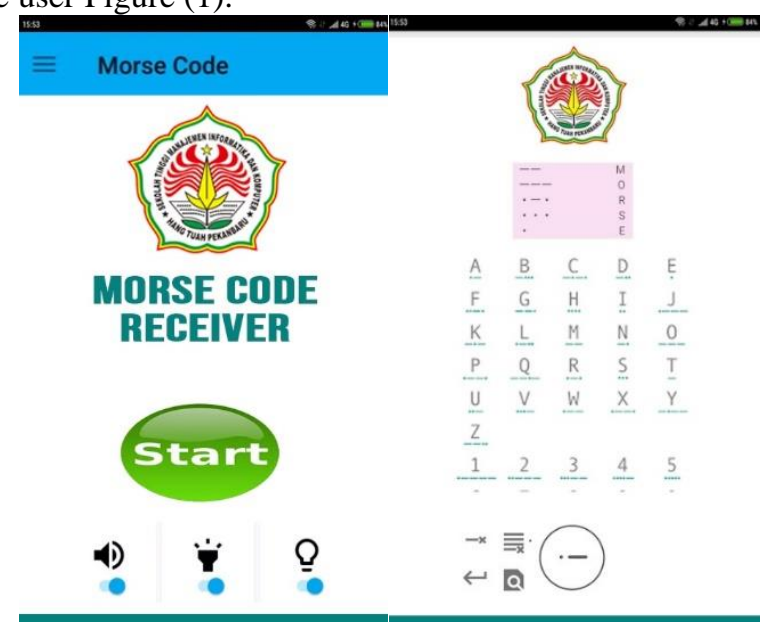

Fig. 1. Home Display and Display Running Process

\section{A. System Testing}

After the implementation stage is carried out, it is followed by the testing phase (Figure 2). The testing phase is carried out to determine the suitability between the results of the implementation and the predetermined needs analysis. Blackbox testing is carried out to find out whether the system built has been running in accordance with the results of analysis and design, as well as according to needs.

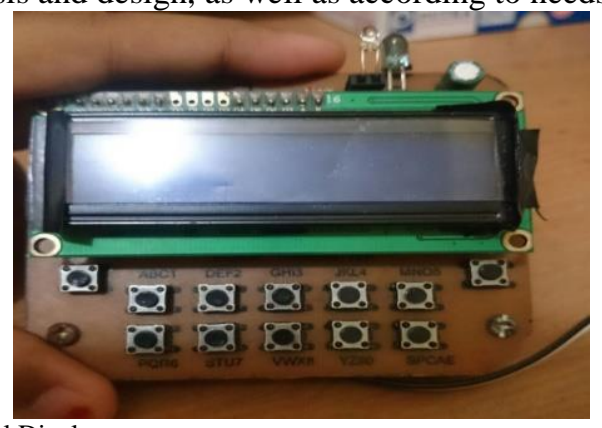

Fig. 2. Tool Display

\section{B. Process button}

The process button is a button that is used to run the infrared ray detection process (Figure 3). 


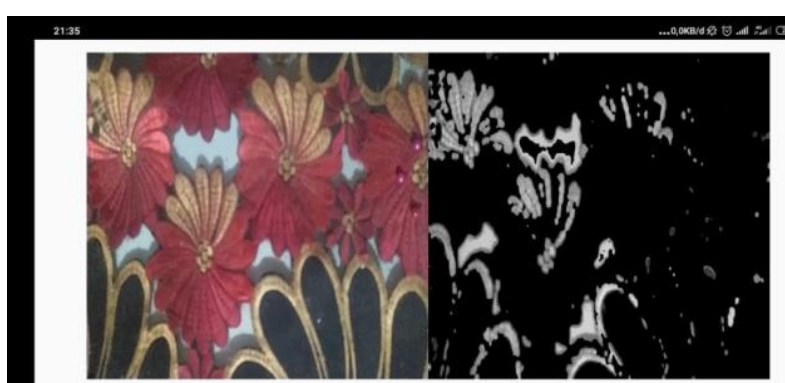

Fig. 4. Display of Current Processes

To detect infrared light based on the color of the video file, image processing is needed. Where the image input in the image processing process in this system is obtained from the image taking or image acquisition process whose output is an image that has an RGB value.

In the image processing process, to detect infrared light based on the color of the RGB image input, in general, the process is the image subtraction method. RGB image input obtained from the image capture process will then be processed using the image subtraction method to detect infrared light on the RGB image input.

The following is an image processing process in an infrared light detection system:

1. RGB Image Input. RGB image input is obtained from the image acquisition process. After the system gets RGB image input, the first step is to capture the video file and split it into digital images based on video frames. The extraction process is carried out on video where each frame at a certain time unit is converted into a digital image. The resulting digital image is in the form of JPEG (Joint Photographic Experts Group). Furthermore, for each pixel in the digital image it is converted to double type which has a value range of 0 to 1. A pixel value of 0 is for a weak color component and a value of 1 means a strong color component.

2. Based on the image generated from the video recording, a background model is determined. Then the background image modeling process is carried out manually by selecting a digital image where there are no objects in it.

3. After the image has been normalized, the background subtraction process is then carried out by reducing each pixel in the object image with the background image. The image reduction process is done in absolute terms where the difference of each pixel of the two images will be obtained and always have a positive value. Because this technique will see the difference for each pixel in the image, so both images must have the same data type and size.

4. Median Filter. The results of the image subtraction are then processed using the median filter function to clarify the results of the subtracting and remove salt and pepper noise (noise), then several processes of strengthening (dilatatio) and filling (fill) are carried out.

5. After the object is well segmented, a selection is carried out by performing a classification so that the infrared light object and the non-infrared light object are obtained.

6. After the classification of infrared light objects and noninfrared light objects, the classified object is marked with a circle. Circles are created based on the outer boundary of each object.

Blackbox testing is carried out to find out whether the system built has been running in accordance with the results of analysis and design, as well as according to needs. Blackbox testing is also used to see how the system condition is when it has been run. The results of testing using the blackbox method on the system that have been built are showing in Table I.

TABLE I. HOME TESTING RESULTS

\begin{tabular}{|l|l|l|l|l|}
\hline $\begin{array}{l}\text { Testing } \\
\text { Procedure }\end{array}$ & Description & $\begin{array}{l}\text { Expected } \\
\text { output }\end{array}$ & Result & Information \\
\hline $\begin{array}{l}\text { Click the } \\
\text { start button }\end{array}$ & $\begin{array}{l}\text { Test to display } \\
\text { the start page }\end{array}$ & $\begin{array}{l}\text { The system } \\
\text { will display } \\
\text { a start page }\end{array}$ & $\begin{array}{l}\text { Displays } \\
\text { the start } \\
\text { page }\end{array}$ & Be accepted \\
\hline
\end{tabular}

The Table II shows the results of the tests carried out on the image capture page with the following results:

TABLE II. TESTING THE TAKE IMAGE MENU

\begin{tabular}{|c|c|c|c|c|c|}
\hline $\begin{array}{l}\text { Testing } \\
\text { Procedure }\end{array}$ & Input & $\begin{array}{l}\text { Expected } \\
\text { Output }\end{array}$ & $\begin{array}{l}\text { Evaluation } \\
\text { Criteria }\end{array}$ & $\begin{array}{l}\text { The results } \\
\text { obtained }\end{array}$ & Information \\
\hline $\begin{array}{l}\text { Click the } \\
\text { menu } \\
\text { select } \\
\text { start on } \\
\text { the } \\
\text { system }\end{array}$ & - & $\begin{array}{l}\text { The system } \\
\text { displays an } \\
\text { image data } \\
\text { page. }\end{array}$ & $\begin{array}{l}\text { The } \\
\text { screen } \\
\text { displays } \\
\text { the image } \\
\text { data page } \\
\text { to be } \\
\text { detected. }\end{array}$ & $\begin{array}{l}\text { The system } \\
\text { successfully } \\
\text { displays the } \\
\text { page select } \\
\text { the image } \\
\text { correctly. }\end{array}$ & $\begin{array}{l}\mathrm{Be} \\
\text { accepted }\end{array}$ \\
\hline $\begin{array}{l}\text { Click the } \\
\text { start } \\
\text { button }\end{array}$ & $\begin{array}{l}\text { Infrared } \\
\text { light }\end{array}$ & $\begin{array}{l}\text { The system } \\
\text { will run } \\
\text { immediately } \\
\text { displayed } \\
\text { on the main } \\
\text { page of the } \\
\text { system. }\end{array}$ & $\begin{array}{l}\text { The } \\
\text { screen } \\
\text { displays } \\
\text { the data } \\
\text { for the } \\
\text { selected } \\
\text { image. }\end{array}$ & $\begin{array}{l}\text { The system } \\
\text { successfully } \\
\text { displays the } \\
\text { selected } \\
\text { image data } \\
\text { that will be } \\
\text { processed. }\end{array}$ & $\begin{array}{l}\mathrm{Be} \\
\text { accepted }\end{array}$ \\
\hline
\end{tabular}

From the Blackbox testing that has been carried out, it can be concluded that the Background Subtraction system in the design of the Morse sign language receiver on the Android-based invisible light has worked as expected and the suitability of the functions that have been implemented is in accordance with the results of analysis and planning.

\section{Conclusion of System Testing}

To determine the level of testing accuracy, an accuracy calculation is performed using the FMR (False Match Rate) based on the number of rays that have been tested. Based on the test results above, the following test results are obtained by Calculation error ratio (FMR) as

$$
\frac{\text { The number of characters counted success fully }}{\text { Number of test characters }} \times 100 \%=\frac{17}{26} \times 100 \%=65 \%
$$

After testing, the test results are obtained which can be seen in Table III.

\section{TABLE III. SYSTEM TESTING CONCLUSION}

\begin{tabular}{|c|c|c|c|}
\hline $\begin{array}{c}\text { Total Character } \\
\text { Data } \\
(1)\end{array}$ & $\begin{array}{c}\text { Successfully } \\
\text { calculated } \\
(2)\end{array}$ & $\begin{array}{c}\text { Failed to } \\
\text { Calculate } \\
(3)\end{array}$ & $\begin{array}{c}\text { Percentage of } \\
\text { Success } \\
(4)=2 / 1 * 100\end{array}$ \\
\hline 26 & 17 & 9 & $65 \%$ \\
\hline
\end{tabular}

\section{CONCLUSION}

Based on the results of the research that has been done, it can be concluded that the system is able to detect infrared light at the transmitter. Implementation carried out, in 
accordance with analysis and design. The level of accuracy of testing using the False Match Rate (FMR) obtained a success percentage of $65 \%$ of the 26-character data tested. From the 26-character data tested, it was obtained data with the number of characters that were successfully counted correctly, namely 17 characters, while the character data that failed to be counted was 9 characters with a detection result of 26 characters.

\section{REFERENCES}

[1] Nilas, Phongchai. A PDA-based human-robot interaction using EMG-based modified morse code. In: International Conference on Computational Intelligence for Modelling, Control and Automation and International Conference on Intelligent Agents, Web Technologies and Internet Commerce (CIMCA-IAWTIC'06). IEEE, 2005. p. 1011-1016.

[2] Ming-Che Hsieh, Ching-Hsing Luo and Chi-Wu Mao, "Unstable Morse code recognition with adaptive variable-ratio threshold prediction for physically disabled persons," in IEEE Transactions on Rehabilitation Engineering, vol. 8, no. 3, pp. 405-413, Sept. 2000, doi: $10.1109 / 86.867882$.

[3] Ching-Hsing Luo and Duu-Tong Fuh, "Online Morse code automatic recognition with neural network system," 2001 Conference Proceedings of the 23rd Annual International Conference of the IEEE Engineering in Medicine and Biology Society, Istanbul, Turkey, 2001, pp. 684-686 vol.1, doi: 10.1109/IEMBS.2001.1019028.

[4] Wahyuni, Refni; Irawan, Yuda. Web-Based Employee Performance Assessment System in PT. Wifiku Indonesia. Journal of Applied Engineering and Technological Science (JAETS), 2020, 1.2: 60-69.

[5] R. Li, M. Nguyen and W. Q. Yan, "Morse Codes Enter Using Finger Gesture Recognition," 2017 International Conference on Digital Image Computing: Techniques and Applications (DICTA), Sydney, NSW, 2017, pp. 1-8, doi: 10.1109/DICTA.2017.8227464.

[6] Irawan, Yuda. "Implementation Of Data Mining For Determining Majors Using K-Means Algorithm In Students Of SMA Negeri 1 Pangkalan Kerinci." Journal of Applied Engineering and Technological Science (JAETS) 1.1 (2019): 17-29.

[7] K. Niu et al., "WiMorse: A Contactless Morse Code Text Input System Using Ambient WiFi Signals," in IEEE Internet of Things Journal, vol. 6, no. 6, pp. 9993-10008, Dec. 2019, doi: 10.1109/JIOT.2019.2934904.

[8] A. Murugan and R. Thilagavathy, "Cloud storage security scheme using DNA computing with morse code and zigzag pattern," 2017 IEEE International Conference on Power, Control, Signals and Instrumentation Engineering (ICPCSI), Chennai, 2017, pp. 22632268, doi: 10.1109/ICPCSI.2017.8392120.

[9] D. G. Subagjo, A. Nurhakim, R. Anggriawan, H. M. Saputra, R. Arief Subekti and A. Rajani, "Digital Portable Morse Code Signaling Device Based on Intermittent Light," 2018 International Conference on Radar, Antenna, Microwave, Electronics, and Telecommunications (ICRAMET), Serpong, Indonesia, 2018, pp. 51-54, doi: 10.1109/ICRAMET.2018.8683937.

[10] Muhardi, Muhardi, et al. "Design Of Web Based LMS (Learning Management System) in SMAN 1 Kampar Kiri Hilir." Journal of Applied Engineering and Technological Science (JAETS) 1.2 (2020): 70-76.

[11] C. Lee, C. Wu, B. Su and T. Shen, "A novel electronic lock using ultrasound Morse code based on FIR filter," 2016 International Conference on Advanced Materials for Science and Engineering (ICAMSE), Tainan, 2016, pp. 227-230, doi: 10.1109/ICAMSE.2016.7840293.

[12] J. F. Cunniff and C. E. Theall, "Transistor morse-to-teleprinter code converter," in Transactions of the American Institute of Electrical Engineers, Part I: Communication and Electronics, vol. 80, no. 2, pp. 178-181, May 1961, doi: 10.1109/TCE.1961.6373097.

[13] Q. Shanhu, L. Hongbo and Z. Xu, "Morse Recognition Algorithm Based on K-means," 2019 Cross Strait Quad-Regional Radio
Science and Wireless Technology Conference (CSQRWC), Taiyuan, China, 2019, pp. 1-2, doi: 10.1109/CSQRWC.2019.8799149.

[14] Jiang, Zhiping, et al. "Eliminating the Barriers: Demystify Wi-Fi Baseband Design And Introduce PicoScenes Wi-Fi Sensing Platform." arXiv preprint arXiv:2010.10233 (2020).

[15] Irawan, Y., Fernando, Y., \& Wahyuni, R. Detecting Heart Rate Using Pulse Sensor As Alternative Knowing Heart Condition. Journal of Applied Engineering and Technological Science (JAETS),2019, 1(1), pp 30-42.

[16] Song, Hang, et al. WiEps: Measurement of Dielectric Property with Commodity WiFi Device--An application to Ethanol/Water Mixture. arXiv preprint arXiv:2003.01622, 2020.

[17] Regani, Sai Deepika, et al. Time Reversal Based Robust Gesture Recognition Using Wifi. In: ICASSP 2020-2020 IEEE International Conference on Acoustics, Speech and Signal Processing (ICASSP). IEEE, 2020. p. 8309-8313.

[18] Zeng, Youwei, et al. A multi-person respiration monitoring system using COTS wifi devices. In: Adjunct Proceedings of the 2020 ACM International Joint Conference on Pervasive and Ubiquitous Computing and Proceedings of the 2020 ACM International Symposium on Wearable Computers. 2020. p. 195-198.

[19] Irawan, Yuda, Yunior Fernando, and Refni Wahyuni. "Detecting Heart Rate Using Pulse Sensor As Alternative Knowing Heart Condition." Journal of Applied Engineering and Technological Science (JAETS) 1.1 (2019): 30-42.

[20] Zeng, Youwei, et al. MultiSense: Enabling multi-person respiration sensing with commodity wifi. Proceedings of the ACM on Interactive, Mobile, Wearable and Ubiquitous Technologies, 2020, 4.3: $1-29$.

[21] Hao, Zhanjun, et al. Wi-SL: Contactless Fine-Grained Gesture Recognition Uses Channel State Information. Sensors, 2020, 20.14: 4025 .

[22] Wahyuni, Refni; Irawan, Yuda. Web-Based Employee Performance Assessment System in PT. Wifiku Indonesia. Journal of Applied Engineering and Technological Science (JAETS), 2020, 1.2: 60-69.

[23] Chen, Weiyan, et al. Robust Dynamic Hand Gesture Interaction using LTE Terminals. In: 2020 19th ACM/IEEE International Conference on Information Processing in Sensor Networks (IPSN). IEEE, 2020. p. 109-120.

[24] Fonda, H. (2020). Klasifikasi Batik Riau Dengan Menggunakan Convolutional Neural Networks (Cnn). Jurnal Ilmu Komputer, 9(1), 7-10.

[25] Nalajala, Paparao, et al. Morse code generator using microcontroller with alphanumeric keypad. In: 2016 International Conference on Electrical, Electronics, and Optimization Techniques (ICEEOT). IEEE, 2016. p. 762-766.

[26] Suparman, Wafiuddin; HOMAM, Mariyam Jamilah. Development of transmitter and receiver for fox hunting activity. In: AIP Conference Proceedings. AIP Publishing LLC, 2019. p. 020020.

[27] Lenardo, Gilang Citra, et al. Pemanfaatan Bot Telegram sebagai Media Informasi Akademik di STMIK Hang Tuah Pekanbaru. JTIM: Jurnal Teknologi Informasi dan Multimedia, 2020, 1.4: 351-357.

[28] CHEN, Qijun; CANNON, Ben. Method and system for unlocking vehicle with use of morse code. U.S. Patent No 10,081,334, 2018.

[29] SILVA, Sérgio, et al. Morse code translator using the Arduino platform: Crafting the future of microcontrollers. In: 2016 SAI Computing Conference (SAI). IEEE, 2016. p. 675-680.

[30] Irawan, Yuda. Penerapan Data Mining Untuk Evaluasi Data Penjualan Menggunakan Metode Clustering Dan Algoritma Hirarki Divisive Di Perusahaan Media World Pekanbaru. Jurnal Teknologi Informasi Universitas Lambung Mangkurat (JTIULM), 2019, 4.1: 13-20.

[31] Mohammad Faudzi, Nurazrina. Morse code security system via visible light communication using MATLAB. 2015. PhD Thesis. Universiti Tun Hussein Onn Malaysia.

[32] Fatmawati, Kiki, et al. Rancang Bangun Tempat Sampah Pintar Menggunakan Sensor Jarak Berbasis Mikrokontroler Arduino. Riau Journal Of Computer Science, 2020, 6.2: 124-134.

[33] Wijaya, Nur Hudha, et al. The Design of Heart Rate Detector and Body Temperature Measurement Device Using ATMega16. Journal of Robotics and Control (JRC), 2020, 1.2: 40-43. 